Kecskeméti Judit ${ }^{1}-$ D. Molnár Éva

${ }^{1}$ Lázár Vilmos Általános Iskola

${ }^{2}$ SZTE Neveléstudományi Intézet

\title{
8. és 9. évfolyamos tanulók földrajztanulásának sajátosságai a tanítási módszerekkel összefüggésben
}

Napjainkban egyre inkább fokozódik a tanulás iránti érdeklódés, hisz a gyarapodó társadalmi és gazdasági változások indokolttá teszik, hogy az oktatási rendszerból olyan tanulók

kerüljenek ki, akik hatékonyan tudnak alkalmazkodni a munkaerố-piaci változásokhoz (D. Molnár, 2013). Ennek egyik feltétele, hogy a tanulók a tanulás komplex rendszerének eredményes múködtetése érdekében megfeleló tanulási stratégiákat sajátítsanak el

az iskolában, melyet hatékony motivációs összetevókkel képesek párositani. Ugyanakkor az is lényeges, hogy a pedagógusok hatékony tanítási stratégiákat alkalmazzanak, melyekkel segithetik a diákokat a tanulás folyamatában és a tananyag megértésében (vö. Bekéné, 2012; Tóthné, 2011).

M indemellett fontos az is, hogy az eddigi szakirodalmi áttekintések mellett ne csak általánosságban bővítsük ismereteinket a tanulásról, hanem tantárgyspecifikusan is vizsgálódjunk (Csikos, 2012). Pontosabb következtetéseket vonhatunk le, ha egy adott tantárgy keretében figyeljük meg, hogy a tanulás iránti motiváció kialakítása és fenntartása, a belső (pl. érdeklődés) és külső motívumok (pl. szociális környezet) fejlesztése hogyan segíti a hatékony tanulási stratégiák kiválasztását és müködtetését is (Bekéné, 2012; Tóthné, 2011).

Igazolt tény, hogy az életkor előrehaladtával a természettudományos tantárgyak iránti érdeklődés csökken (Csapó, 2000; Csullog, D. Molnár és Lannert, 2014), s hogy ehhez hozzájárul az iskolai szerkezetváltás is, mivel visszaesik az elsajátítási motívumok domináns szerepe az iskolai eredményességben (Józsa és Fejes, 2012).

Jelen tanulmányban megvizsgáljuk, hogy a földrajz esetén mennyiben igazolhatók a természettudományos tantárgyak kapcsán kapott eddigi kutatási eredmények mind a motiváció, mind a stratégiahasználat terén, s ezek milyen összefüggést mutatnak a tanítási módszerekkel. Továbbá az iskolai szerkezetváltás szerepét is ellenőrizzük a 8. és 9. évfolyamos diákok és tanáraik eredményei kapcsán. A kutatás során bemért kérdőíveket használtunk, s alakítottuk át speciálisan a földrajz tantárgyra vonatkozóan. 


\section{A földrajzoktatás helyzete napjainkban}

Magyarországon a földrajz tanítását kezdetben annak leíró jellege határozta meg. Az 1960-as évektől „oknyomozó” jellegüvé vált, mivel ekkor már ok-okozati összefüggéseket próbáltak feltárni az ismeretek között. Ezt követően, az 1990-es években már a „prognosztizáló” földrajztanítás vált dominánssá, ahol a fö hangsúlyt a problémafelvető kérdések kapták (Farsang, 2011).

A földrajzot hazánkban sokáig a történelemmel kapcsolták össze a 17-18. században (Farsang, 2011). Ugyanakkor a földrajz számos tantárggyal mutat szoros kapcsolatot, mint például: természetismeret, matematika, magyar irodalom, fizika, biológia, történelem vagy az idegen nyelv (Ütöné, 2009). Ezen különböző tantárgyakban szerzett ismeretek meghatározóak lehetnének a tanult jelenségek, folyamatok, törvényszerüségek megértéséhez (Ütőné, 2009).

Az eddigi oktatáspolitikai intézkedések többsége azonban elhatárolódott a domináns természettudományos tantárgyak, vagyis a fizika, kémia, biológia és földrajz „,szentnégyesének" egységesítésétől, annak ellenére, hogy az integrálás sokkal színesebbé tehetné az oktatás folyamatát, mind a tanárok, mind a diákok számára (Nahalka, 2013).

A földrajz mint müveltségterület hozzájárul a természettudományos szemlélet és gondolkodás kialakításához, ugyanakkor valamiféle ambivalens viszonyt is létrehoz a többi természettudományos tantárggyal kapcsolatban. Ez a kettős viszony egyrészt annak köszönhetö, hogy számtalan olyan földrajzi ismeretet kell elsajátítani, elsajátíttatni, melyekhez egy másik (ugyancsak természettudományos) tantárgy ismerete lenne szükséges (lásd fentebb), azért hogy bizonyos jelenségeket könnyen és gyorsan megértsenek, másrészt a földrajz tantárgy oktatása a középiskola 10. évfolyamát bezárólag befejeződik, s nincsenek további építkezési lehetőségek. Problémát okoz ez azért is, mert gátolja a történelem tantárggyal közös ismeretek hatékony integrációját is, s szintetizáló jellegü elsajátításra készteti a tanulót, mely sokszor az életkori sajátosságokkal sem egyeztethető össze mindenben (Ütőné, 2002). Ha a tanulók számára a tananyag elszakad az általuk ismert jelenségektől, akkor nem éreznek majd motiváltságot arra vonatkozólag, hogy összefüggéseket keressenek a mindennapi jelenségek és az iskolában hallott tudományos tények között (Korom és Csapó, 1997).

Az elmúlt évtizedek oktatáspolitikájának káros következményei között tartják számon, hogy az általános iskolában meglehetősen kevés és bizonytalan alapokra tudnak majd csak építkezni mind a tanárok, mind a tanulók (Makádi és Horváth, 2011). Ez egyrészt következménye lehet annak is, hogy a tanárok nem diagnosztizálták a tanulók előismereteit, pedig az új fogalmak hatékony beépülését csak úgy segíthetik elő, ha tudatosan nyomon követik az előzetes és a ráépülő új ismeretet, hisz a diákok nem rendelkeznek azokkal a sémákkal, melyekre a szaknyelvi magyarázatot lehetne építeni (Korom és Csapó, 1997).

A földünk és környezetünk müveltségterület oktatása ma $(N A T, 2012)$ 5. évfolyamon kezdődik, s az 5-6. osztályban még az Ember és természet, valamint az Ember és társadalom fejlesztési követelményeihez is kapcsolódik. A NAT (2012) ma már csak fejlesztési területekre és közmüveltségi tartalmakra ad meg irányelveket, azonban az időkeretet nem határozza meg. Ugyanakkor nem bontja külön az egyes évfolyamokhoz tartozó követelményeket, hanem az 5-8. és a 9-12. évfolyamhoz tartozó irányelveket is egy blokkban fogalmazza meg (NAT, 2012).

Nemzetközi szinten a brit és a román minta mutat különbözőséget ebben a régióban. A brit iskolákban a földrajz tanításának egyik eltérő formája jelent meg, melyet újfajta földrajztanítási stratégiaként fogtak fel, s melyet ,gondolkodtató földrajztanítás” néven vezettek be. Ezen újfajta szemlélet középpontjában az a folyamat áll, hogy ,,a diákok hogyan tanulnak, és a tanárok hogyan avatkoznak be a tanulás folyamatába" (Chandler, 
2011, 5.o.). Az elsődleges cél a módszerek kiválogatásánál az volt, hogy a tanárok diákjaik metakognitív folyamatait fejlesszék, ami révén egyre mélyrehatóbban ismerkedhetnek meg a tanulók saját gondolkodásukkal és tanulási folyamataikkal, s egyúttal lehetőséget kapnak arra, hogy megismerkedjenek a föbb földrajzi koncepciókkal, mely lehetővé teszi a tantárgyak közötti kapcsolatok felfedezését is (Chandler, 2011). A legsikeresebb ezen módszerek között a „térképmemori”, mely több részfolyamatból áll: az azonosításból, a felismerésből és az értelmezésből. Ez a módszer segítséget nyújt abban is, hogy a tanulók önálló tapasztalatszerzés által kritikus gondolkodókká, s ezzel együtt önálló tanulókká váljanak. Összességében olyan visszajelzést ad, amely kellő gondolkodási idő biztosításával lehetővé teszi a gondolkodási folyamat sebességének megállapítását is, s ezáltal folyamatos és változatos gondolkodásra ösztönzi a diákokat (Chandler, 2011). A módszer megfelelő elterjesztése és alkalmazása azonban még hiányosnak mondható, hisz saját tapasztalatra épülő kézikönyvnek tekinthetö, amely konkrét statisztikai eredmények hiányában csak az egyéni önreflexión alapul.

Romániában azzal kísérleteztek, hogy a földrajzoktatást a tanulók érdeklődéséhez igazítsák, ami másfajta tanulási és tanítási stratégiák alkalmazását igényelte mind a tanár, mind a diák oldaláról. Ez elsősorban azt jelentette, hogy mindenki azt tanulhatta, és úgy, ahogy számára az a legérdekesebb volt. 2011-től vezették be a földrajzot mint kötelezően választható tantárgyat, mely során elsődlegesen a kreatív gondolkodás fejlesztését jelölték meg legfontosabb célként. Ezen kísérlet azonban a módszer hibáit is kihangsúlyozta, miszerint a tananyag mennyisége még mindig nagymértékü és egyes témákban a gyakorlati alkalmazhatóság helyett még mindig az elmélet hangsúlyozása valósult meg (Jucu, 2012).

Összességében elmondható, hogy a magyarországi földrajzoktatás jellege az elmúlt évtizedekhez képest jelentősen megváltozott, azonban mégsem tud jelenleg olyan fejlődést, illetve arra való jelentősebb törekvést bemutatni, mint amilyent akár Romániában, akár Nagy-Britanniában igyekeztek elérni.

\section{A földrajz tantárgy megjelenése a tanitási és tanulási folyamatban}

A tanítási és tanulási folyamat megtervezése és irányítása a földrajzoktatásban is kiemelten fontos kutatási területnek számít, hisz meghatározó jelentőségü, hogy a tanulók mennyi lehetőséget kapnak egyáltalán a kezdeményezésre, a cselekvő aktivitásra és az alkotó önállóságra (Kormány, 2014).

A földrajz tantárgy esetében mind a tanulási, mind a tanítási folyamaton belül a legnagyobb hangsúly a megtanulandó tényanyagra helyeződik (Makádi, Farkas és Horváth, 2013). A tanulók leginkább a rendelkezésükre álló tankönyvekből, tanári magyarázatból, tanórai feladatokból, szülőktől, tévémüsorokból, folyóiratokból, egyéb könyvekből, valamint az internetről szerzik tapasztalataikat (Kádár és Farsang, 2012). A földrajznak bár számos sajátos előnye van (például: kapcsolatot teremt az ember és a környezet között), mégis a túlságosan szerteágazó volta miatt, nehézséget teremthet a tanulási-tanítási folyamatban egyaránt (Hinde, 2015). Sajátos, csak a földrajzra jellemző tanulási és tanítási stratégia nem ismert, azonban azon általános tanulási és tanítási stratégiák használata eredményes, amelyek révén a tananyag feldolgozása, megértése és mindennapi élethelyzetekben való alkalmazása megvalósulhat.

Hétköznapi értelemben a stratégia valamilyen összetett és átfogó tervet jelent (Ollé, 2010). Ha tudományos értelemben közelítjük meg a tanulási stratégia fogalmát, akkor szemléletmódtól függően számos értelmezési lehetőségre bukkanhatunk. Bár a megközelítések szerteágazóak lehetnek, az eltérő elméletek rendre ugyanarra a gondolatra vezet- 
hetők vissza, melyek közül Lappints $(2002,89$. o.) definíciója a legjobb összefoglalása a fogalomnak, miszerint a tanulási stratégia nem más, mint „, a tanulásra vonatkozó tervek, elhatározások rendszere, amelyek meghatározott célokra irányulnak, és amelyekre bizonyos tartósság és elrendezés jellemzö". Ahhoz azonban, hogy az egyén megfelelö stratégiákat tudjon kialakítani, mindenképpen szüksége van saját tapasztalatok szerzésére, $\mathrm{s}$ ebben a folyamatban kiemelt jelentösége van mind az oktatásnak, mind az önálló tanulás folyamatának (Kálmán, 2009).

Paul Pintrich (1989) a tanulási stratégiákat három nagy csoportba sorolja: kognitív, metakognitív és forráskezelő tanulási stratégiák. A következőkben ezeket a csoportokat mutatjuk be röviden D. Molnár (2013), valamint Csullog és munkatársai (2014) munkái alapján.

A kognitív stratégiákhoz azok a stratégiák tartoznak, melyek az információ kezelésével, a tananyag feldolgozásával és rögzítésével, a memorizálással kapcsolatosak, s melyekhez az ismétlés, kidolgozás és elrendezés/szervezés folyamatai tartoznak. A metakognitív stratégiák során azok a folyamatok müködnek, melyek segítségével a tanuló a saját tanulási folyamatát kontrollálni tudja: tervezés, nyomon követés és ellenőrzés. A forráskezelő stratégiák által a tanulók a környezeti és belső erőforrásokat kontrollálják, s ezáltal saját céljaikat összehangolják a kontextus változásával (Csullog és mtsai, 2014; D. Molnár, 2013).

A tanítási stratégia, a tanulási stratégiához hasonlóan valamiféle folyamattervként fogható fel, hisz egy előre megadott tanítási cél eléréséhez segíti a résztvevőket (Mansfield és Volet, 2010). Fontos ugyanakkor megemlíteni azt is, hogy a tanítás nem eredményez azonnali tanulási folyamatot, bár a kettő egymással szorosan összefüggő folyamatnak tekinthető. A tanulási és a tanítási stratégiák között akkor lép fel összhang, ha a korábban elsajátított tanulási stratégiát a diákok a megfelelő helyzetben is tudják majd alkalmazni (Vermunt és Verloop, 1999).

Vermunt és Verloop (1999) háromféle tanítási stratégiát különböztet meg: (1) erős tanári kontroll stratégiája (a tanár átveszi a diákoktól a kognitív, a metakognitív és az affektív tevékenységek elvégzését), (2) feladatirányítás stratégiája (ahol a tanulás funkciói iránti felelősséget átruházza a diákokra) és (3) közös ellenőrzés iránti stratégia (a tanulási tevékenység során a feladatok már megoszlanak a résztvevők között, vagyis a diákok megvalósítják a tanulás funkcióit, a tanárok pedig ezt a folyamatot ösztönzik).

A PISA-mérések alapján kiderült, hogy a magyar diákok leginkább a memorizálás stratégiáját alkalmazzák tanulásuk során (B. Németh és Habók, 2006; Csullog és mtsai, 2014), ami a legkevésbé sem segíti a tananyag mélyebb feldolgozását és hatékony alkalmazhatóságát. A tanítási stratégiák földrajzórán való alkalmazásáról kevés kutatási adat áll rendelkezésünkre, azonban többen kiemelik az önálló aktivitást szolgáló, felfedeztető stratégia szerepét a földrajzoktatásban (Horváth H., 2009; Kormány, 2014; Makádi és mtsai, 2013).

\section{A földrajz tantárggyal kapcsolatos motívumok}

Az iskolai eredményesség és a tanulási motívumok kapcsolatát már korábbi vizsgálatok is igazolták (Józsa, 2007). Ezek a kutatások ezzel egyidejüleg elismerték azt is, hogy a motívumok müködése pontosan csak abban a környezetben értelmezhetők, melyben maga a tanulás zajlik (Csíkos, 2012; Józsa és Fazekasné, 2007).

Többen beszámoltak a természettudományos tantárgyak iránti érdeklödés életkor elörehaladtával történö folyamatos csökkenéséröl (Csapó, 2000; Csullog és mtsai, 2014; Józsa és Fejes, 2012). Az érdeklődés fontos tényezőként funkcionál, hisz kritikus feltételként tartják számon (Hidi, 2001), mely jelentős hatással van az iskolában elért 
eredményességre (Csullog és mtsai, 2014). A földrajz helyzete a természettudományos tantárgyakon belül ugyanakkor az érdeklődés vonatkozásában viszonylag kedvezőnek tekinthető, hisz a legtöbben „változatosnak”, „fontosnak”, ,érdekesnek” és „,hasznosnak” ítélik meg, bár a tantárgyak közötti kedveltségi hierarchiában alacsonyabb fokon áll, mint a számítástechnika vagy a testnevelés (Takács, 2001). Ez a megállapítás ugyanakkor némileg ellentmond annak, hogy bár a tanulók nagy százaléka érdekesnek tartja magát a tantárgyat, de a legtöbben mégsem kedvelik. Ezt bizonyítja az is, hogy a korábban elvégzett kutatások szerint a megkérdezett tanulók kétharmada a fizika, a földrajz és

... a korábban elvégzett kutatások szerint a megkérdezett tanulók kétharmada a fizika, a földrajz és a matematika hármasát jelölte meg, mint a legkevésbé kedvelt tantárgyak valamelyikét (Csíkos, 2012). Valószinúsithetó azonban, hogy ez következmé-

nye annak a kutatási eredménynek, miszerint a természettudományos érdeklódés kialakitásáért elsốsorban az általános iskola, s az ott tanító tanárok a felelösek, mivel ott találkoznak elóször a tanulók ezen tantárgyak tartalmával, szemléletével, s a középiskolában már a hangsúly nem az adott tantárgyra, hanem a tantárgyak közötti tananyagok összekapcsolására, átlátására és megértésére vonatkozik (Nagy, 2010). a matematika hármasát jelölte meg, mint a legkevésbé kedvelt tantárgyak valamelyikét (Csíkos, 2012). Valószínüsíthető azonban, hogy ez következménye annak a kutatási eredménynek, miszerint a természettudományos érdeklődés kialakításáért elsősorban az általános iskola, s az ott tanító tanárok a felelösek, mivel ott találkoznak először a tanulók ezen tantárgyak tartalmával, szemléletével, s a középiskolában már a hangsúly nem az adott tantárgyra, hanem a tantárgyak közötti tananyagok összekapcsolására, átlátására és megértésére vonatkozik (Nagy, 2010).

A tanulási motívumok kialakításában és fejlesztésében a szülőknek, a pedagógusoknak és a kortársaknak van a legnagyobb hatásuk. A családi szféra kiemelten fontos szerepét számos kutatás igazolta (lásd Csapó, 2003, idézi Józsa és Fejes, 2012), hisz az eltérő szociokulturális háttérből érkező gyerekek között jelentős különbség figyelhető meg mind a készségek, mind a képességek fejlettségét tekintve (Józsa és Fejes, 2012). Ugyanakkor a szociális környezetben a pedagógus szerepe is kiemelkedő (Fejes, 2014), hisz a diákok felé irányuló megnyilvánulásai, visszajelzései és elvárásai egyaránt hatnak a tanulók teljesítményére, formálják énképüket, függetlenül attól, hogy azok tudatosnak vagy tudattalannak tekinthetók (Józsa és Fejes, 2012). Meghatározó tehát az is, hogy a tanárok miként vélekednek saját szaktantárgyukról. Az elmúlt évek során számos kutatási eredmény igazolta, hogy a földrajz helyzetének megítélése kapcsán a szülők és a diákok sokkal pozitívabb motívumokkal rendelkeztek a tantárggyal kapcsolatban, mint magát a tantárgyat oktató pedagógusok (Ütöné, 2011). A földrajztanárok kompetenciái az elmúlt időszakban folyamatosan a kutatások középpontjába kerültek, hisz ahhoz, hogy a tanárok saját szaktárgyukat közelebb tudják hozni a diákjaikhoz, bizonyos kötelező feltételeknek teljesülniük kell. Ilyen kiemelt feltételek közé sorolandó például az is, hogy a tanulási folyamatban irányító, segítő és információés értékközvetítő pedagógusként kell részt venniük (Makádi, 2011).

A földrajzzal mint természettudományos tantárggyal kapcsolatos attitüdök vizsgálatát számos tényező befolyásolhatja. Ezek közül az egyik legmeghatározóbb az, hogy integ- 
rált módon tanítják-e a természettudományos tantárgyakat vagy sem (Csapó, 2000). Ha nem integrálták más tantárggyal vagy tantárgyakkal, akkor mind az általános, mind a középiskolában összetömörítették a tananyagot, s a tantárgy specifikusságából adódó elönyöket ki sem bontakoztathatta (Csapó, 2000).

A földrajzzal kapcsolatos motivációs jellemzők növeléséhez tehát mindenképpen szükséges lenne, hogy az integráltság meglététől vagy hiányától függetlenül felmérjük a tanulók előzetes ismereteit, valamint összekapcsoljuk a különböző tudományterületeken szerzett tudásukkal, hogy megfelelő alapokat létrehozva további új ismeretek kibontakozásának adjunk teret, s ezzel együtt hatékonyabban motiváljuk a tanulókat.

\section{Az empirikus vizsgálat módszerei}

Vizsgálatunkban a földrajz tanulásának és tanításának stratégiáit vizsgáljuk 8. és 9. évfolyamos tanulók és tanáraik körében. Célunk ellenőrizni a földrajzzal kapcsolatos tanulási stratégiák és motívumok fejlettségét, az ezt befolyásoló iskolai szerkezetváltás szerepét, valamint a tanítási stratégiákkal mutatott összefüggéseket.

\section{Minta}

A kutatásban összesen 330 tanuló vett részt: 154 nyolcadikos és 176 kilencedikes. Mindkét évfolyam tanulói humán, illetve nyelvtagozatos osztályokból kerültek ki. A nemek a nyolcadikosoknál arányosan, a kilencedikeseknél közel arányosan oszlanak meg (1. táblázat).

1. táblázat. A vizsgálatban részt vevö minta jellemzöi

\begin{tabular}{|l|c|c|c|c|}
\hline \multirow{2}{*}{ Minta } & \multicolumn{2}{|c|}{ N } & \multicolumn{2}{c|}{ Átlagéletkor } \\
\cline { 2 - 5 } & Nyolcadikosok & Kilencedikesek & Nyolcadikosok & Kilencedikesek \\
\hline Fiú & 78 & 80 & 14,15 & 15,43 \\
\hline Lány & 76 & 96 & 14,19 & 15,47 \\
\hline Összesen & 154 & 176 & 14,17 & 15,45 \\
\hline
\end{tabular}

A kutatás során a diákokat tanító tanárokat is felmértük. Jelen esetben hat tanár vett részt a vizsgálatban: két férfi és négy nő, kiknek átlagéletkora a nyolcadik évfolyamos tanárok esetében 49 év, a kilencedikeseknél 45 év.

\section{Eszközök, eljárás}

A vizsgálat eszközeiként két kérdöívet adaptáltunk. Az egyik, Paul Pintrich és munkatársai (1991) magyar nyelvre lefordított MSLQ-kérdőíve (Tanulási motívumok és stratégiák, lásd D. Molnár, 2013), aminek földrajz tantárgyra adaptált változatát használtuk fel. A kérdőív két fö részből áll. Egyik része a motivációs alskála (31 item), mely tartalmazza egyrészt az értékkomponenseket, s azon belül is méri az extrinzik, az intrinzik motivációt, valamint a feladat értékét, másrészt a várakozási komponenseket, $\mathrm{s}$ azon belül a tanulási meggyőződés szabályozását, a tanulás és teljesítmény hatékonyságát, valamint az affektív komponenst, vagyis a teszt-szorongást. Másik része a tanulási stratégiákra vonatkozó alskála (50 item), mely tartalmazza a kognitív és metakognitív stratégiákat: ismétlés, kidolgozás, megszervezés, kritikai gondolkodás, metakognitív önszabályozás; 
a forrás-menedzselő stratégiákat: az idő és környezet, valamint az erőkifejtés, erőfeszítés szabályozása; és a forrás-menedzselésre vonatkozó kitételt: kooperatív tanulás. Összesen 81 tételt tartalmaz, amihez egy hétfokú Likert-skála tartozott (Cronbach $-\alpha=0,94)$.

A másik mérőeszköz az OECD (2012) tanulói kérdőívének tanítási stratégiákra vonatkozó részlete, melynek kijelentéseit módosítottuk speciálisan a földrajzra mind a tanulók, mind a szaktanárok számára (Cronbach $-\alpha: 0,83$ ). A kérdöívnek tanulói és pedagógusi változata is volt, amelyek ugyanazon kijelentéseket tartalmazták. A méröeszköz összesen 4 kérdést és 40 kijelentést tartalmazott, a kérdések közül kettő a földrajzórákra (,,Milyen gyakran fordulnak elö az alábbiak a földrajzóráidon?” „Milyen gyakran történnek az alábbiak a földrajzóráidon?"), kettő a földrajzot tanító tanárra (,,Gondolj arra a földrajztanárra, aki a legutóbbi földrajzórádat tartotta: Milyen gyakran fordulnak elö az alábbiak?” „Mennyire értesz egyet a legutóbbi földrajzórádat tartó földrajztanárral kapcsolatos alábbi állitásokkal?”), valamint 23 kijelentés a földrajzórákra és 17 a földrajztanárra vonatkozott. Ezek a kérdések hat fö területet öleltek fel: 5 item a tanári segítséget, 13 item a tanári viselkedést, azon belül is 5 item a direkt instrukciót, és 4-4 item a tanulói irányultságot, valamint a formatív értékelést mérte. Ezenfelül 9 item a kognitív tevékenységekre, 5 item a tantárgyi klímára, 4 item a tanári támogatásra és 4 item a tanári-osztálymenedzsmentre vonatkozott. A kérdések mellett 1-től 4-ig terjedő Likert-skála szerepelt.

A vizsgálatot 2016 tavaszán bonyolítottuk le, papír-ceruza alapú mérésfelvétellel, felügyelő pedagógusok közremüködésével. A kérdőívek kitöltése mindösszesen 30-35 percet vett igénybe mindkét évfolyamon.

\section{A földrajztanulás stratégiáinak és motívumainak jellemzői}

A földrajz tanulása során alkalmazott tanulási stratégiák esetében az eredmények azt mutatják, hogy a kognitív és metakognitív stratégiákon belül a leginkább előforduló faktor az ismétlés, míg a legalacsonyabb szinten a kritikai gondolkodás jelent meg a tanulók válaszait összesítve. A forráskezelő stratégiák esetében az idő és környezet komponensek használata megelőzi az erőkifejtését. A forrásmenedzselés esetében pedig a segítségkérés a dominánsabb a kooperatív tanulással szemben. Összességében azt láthatjuk, hogy a leggyakrabban alkalmazott stratégia az idő és a környezet menedzselése (ami a földrajz tanulásával kapcsolatos idő kihasználását, a tanulás konkrét helyszínét foglalja magában), míg a legkevésbé alkalmazott a kooperatív tanulási stratégia (többiekkel együtt készülni földrajzból az órákra) (2. táblázat). A két évfolyam eredményeit összehasonlítva, ugyanakkor nem találtunk szignifikáns különbséget a különböző stratégiák alkalmazása terén.

A földrajzzal kapcsolatos tanulási motívumok esetében az értékkomponenseken belül a legmagasabb átlagot az extrinzik motiváció kapcsán kaptuk, míg a legalacsonyabbat a feladat értéke mutatta. A várakozási komponenseket összehasonlítva leginkább a tanulási meggyőződés szabályozása, míg legkevésbé a tanulási és teljesítmény önhatékonyság volt a meghatározó. Ha azonban a motivációs skála minden értékét figyelembe vesszük, akkor leginkább a tanulási meggyőződés szabályozása (a tanulás sikeressége attól függ, mennyi energiát fektet bele a tanuló), legkevésbé előforduló faktor pedig a teszt-szorongás volt (3. táblázat).

Az évfolyamokat összehasonlítva, két esetben látható szignifikáns különbség a motivációs alskálán belül. Egyrészt a feladat értékénél figyelhető meg a különbség a nyolcadikosok javára $(\mathrm{p}=0,03)$, ami azt mutatja, hogy a földrajz tanulásának hasznosságát a kilencedikesek kevésbé tartják fontosnak, mint a nyolcadikosok. Másrészt a várakozási komponenseknél figyelhető meg különbség a tanulási meggyőződés szabályozása ese- 
tében ( $\mathrm{p}=0,01)$, ami azt mutatja a kilencedikesek önjellemzése alapján, hogy jobban tudják irányítani a földrajztanulással kapcsolatos viselkedésüket és erőkifejtésüket, mint a nyolcadikosok. A vizsgált többi motívum esetében szignifikáns különbség nem mutatható ki a két évfolyamot összehasonlítva.

2. táblázat. A földrajzzal kapcsolatos tanulási stratégiák használata évfolyamonként

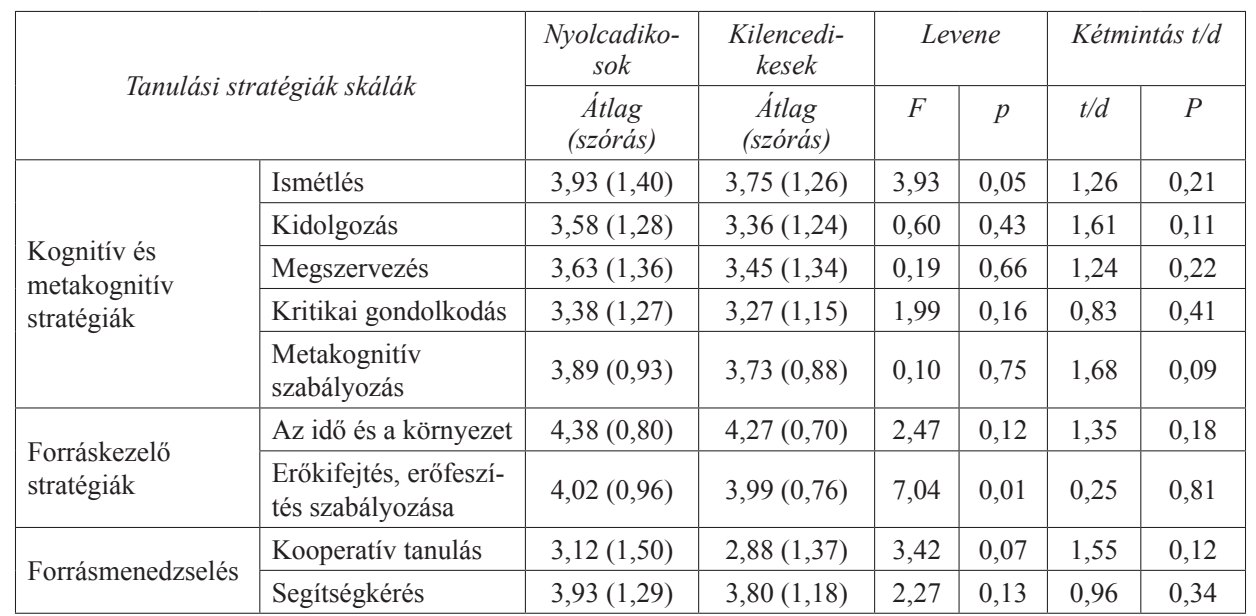

3. táblázat. A földrajzzal kapcsolatos tanulási motívumok fejlettsége évfolyamonként

\begin{tabular}{|c|c|c|c|c|c|c|c|}
\hline \multirow{2}{*}{\multicolumn{2}{|c|}{$\begin{array}{l}\text { Tanulási motívumok skálái } \\
\text { (alskálái) }\end{array}$}} & \multirow{3}{*}{$\begin{array}{c}\begin{array}{c}\text { Nyolcadiko- } \\
\text { sok }\end{array} \\
\text { Átlag (szórás) } \\
4,04(1,30)\end{array}$} & \multirow{3}{*}{$\begin{array}{c}\begin{array}{c}\text { Kilencedi- } \\
\text { kesek }\end{array} \\
\text { Átlag (szórás) } \\
4,07(1,16)\end{array}$} & \multicolumn{2}{|c|}{ Levene } & \multicolumn{2}{|c|}{ Kétmintás $t / d$} \\
\hline & & & & \multirow{2}{*}{$\begin{array}{c}F \\
2,13\end{array}$} & \multirow{2}{*}{$\frac{p}{0,15}$} & \multirow{2}{*}{$\begin{array}{c}t / d \\
-0,22\end{array}$} & \multirow{2}{*}{$\begin{array}{c}p \\
0,82\end{array}$} \\
\hline & Intrinzik motiváció & & & & & & \\
\hline $\begin{array}{l}\text { Ertek- } \\
\text { komnonensek }\end{array}$ & Extrinzik motiváció & $4,84(1,35)$ & $4,45(1,48)$ & 1,79 & 0,18 & 1,92 & 0,06 \\
\hline & Feladat értéke & $4,22(1,35)$ & $3,90(1,34)$ & 0,96 & $<0,01$ & 2,15 & 0,03 \\
\hline \multirow[t]{2}{*}{$\begin{array}{l}\text { Várakozás- } \\
\text { komponensek }\end{array}$} & $\begin{array}{l}\text { A tanulási } \\
\text { meggyőződés } \\
\text { szabályozása }\end{array}$ & $4,63(1,29)$ & $4,98(1,18)$ & 3,75 & 0,05 & $-2,55$ & $<0,01$ \\
\hline & $\begin{array}{l}\text { Tanulási és } \\
\text { teljesítmény } \\
\text { önhatékonyság }\end{array}$ & $4,36(1,36)$ & $4,32(1,41)$ & 0,15 & 0,69 & 0,25 & 0,80 \\
\hline $\begin{array}{l}\text { Affektív } \\
\text { komponens }\end{array}$ & Teszt-szorongás & $3,62(1,34)$ & $3,42(1,43)$ & 1,73 & 0,19 & 1,30 & 0,20 \\
\hline
\end{tabular}

A nemek közötti különbségek vizsgálatában, míg a tanulási stratégiáknál egyetlen esetben sem, a tanulási motívumok során két esetben találtunk szignifikáns különbséget. A földrajztanulással kapcsolatos meggyőződések szabályozásában a lányok magasabb átlagot $(\mathrm{m}=4,95, \mathrm{~s}=1,22)$ mutattak, mint a fiúk $(\mathrm{m}=4,67, \mathrm{~s}=1,26 ; \mathrm{t}=-2,11, \mathrm{p}=0,04)$. Ugyanakkor, úgy tünik, a lányok jobban is szoronganak a földrajzórákhoz kapcsolódó számonkérések során $(\mathrm{m}=3,66, \mathrm{~s}=0,44)$, mint a fiúk $(\mathrm{m}=3,35, \mathrm{~s}=1,32 ; \mathrm{t}=-2,08, \mathrm{p}$ $=0,04)$.

A tanulási stratégiák és motívumok földrajzjeggyel és tanulmányi átlaggal kapcsolatos összefüggés-elemzései során kiderült, hogy a kilencedikes tanulók esetében összességében több és erösebb szignifikáns összefüggés mutatható ki, mint a nyolcadikos tanulóknál. A tanulási motívumok közül a legerősebb összefüggést, mindkét évfolyamon, a 
tanulási és teljesítmény-önhatékonyság mutatta a földrajzjeggyel $\left(\mathrm{r}_{\text {nyolcadik }}=0,56, \mathrm{r}_{\text {kilen- }}\right.$ $\left.{ }_{\text {cedik }}=0,57 ; p=0,01\right)$. További közepesen erös összefüggés adódott még a feladat értéke $\left(\mathrm{r}_{\text {kilencedik }}=0,46 ; \mathrm{p}=0,01\right)$, valamint az intrinzik motívum $\left(\mathrm{r}_{\text {kilencedik }}=0,40 ; \mathrm{p}=0,01\right)$ és a földrajzjegy között. Míg a feladat értéke a nyolcadikosok esetében néhány századdal enyhébb összefüggést jelzett $\left(\mathrm{r}_{\text {nyolcadik }}=0,39 ; \mathrm{p}=0,01\right)$, az ö esetükben az intrinzik motívum nincs is szignifikáns kapcsolatban a földrajzjeggyel, szemben a kilencedikesek eredményével.

A tanulási stratégiák összességében enyhébb összefüggéseket $(\mathrm{r}=0,18-0,25, \mathrm{p}=$ $0,01-0,05)$ mutattak, mint a motívumok a földrajzjeggyel és tanulmányi átlaggal mindkét évfolyamon. Ezek közül kiemelendő az idő és környezet szabályozása $\left(\mathrm{r}_{\text {kilencedik }}=\right.$ 0,$\left.28 ; r_{\text {nyolcadik }}=0,17 ; \mathrm{p}=0,01\right)$, valamint az ismétlés stratégiája $\left(\mathrm{r}_{\text {kilencedik }}=0,25 ; \mathrm{r}_{\text {nyolcadik }}\right.$ $=0,25 ; \mathrm{p}=0,01)$, amik az enyhe korrelációs értékek alapján összefüggnek a földrajzjegy alakulásával.

\section{A földrajztanítással kapcsolatos tapasztalatok}

A földrajztanítással kapcsolatos tanulói megítélések négy esetben mutatnak szignifikáns különbséget a vizsgált évfolyamok között. A „tanári segítség”, a „tanári támogatás”, valamint a „tanári osztály-menedzsment” kategóriákat a kilencedikesek jellemzőbbnek tekintették $(\mathrm{p}<0,01)$, vagyis úgy gondolták, hogy több tanári segítséget és támogatást kapnak, mint a fiatalabb évfolyamosok. A „tantárgyi klíma” esetén a nyolcadikosoknál található magasabb átlag, ami azt mutatja, hogy a földrajzórák hangulatát a nyolcadikosok pozitívabbnak ítélik meg, mint kilencedikes társaik $(\mathrm{p}<0,01)$ (4.táblázat).

4. táblázat. A tanulók földrajztanitással kapcsolatos értékei évfolyamonkénti bontásban

\begin{tabular}{|c|c|c|c|c|c|c|}
\hline \multirow{2}{*}{ Faktorok } & \multirow{2}{*}{$\begin{array}{c}\text { 8. évfolyam } \\
\text { Átlag (szórás) }\end{array}$} & \multirow{2}{*}{$\begin{array}{l}\text { 9. évfolyam } \\
\text { Átlag (szórás) }\end{array}$} & \multicolumn{2}{|c|}{ Levene } & \multicolumn{2}{|c|}{ Kétmintás $t / d$} \\
\hline & & & $F$ & $p$ & $t / d$ & $p$ \\
\hline Tanári segítség & $2,70(0,61)$ & $2,99(0,59)$ & $<0,01$ & 0,96 & $-4,37$ & $<0,01$ \\
\hline Direkt instrukciók & $2,83(0,50)$ & $2,99(0,46)$ & 0,27 & 0,61 & $-2,79$ & 0,06 \\
\hline Tanulói irányultság & $1,61(0,60)$ & $1,62(0,38)$ & 38,84 & 0,00 & $-0,22$ & 0,83 \\
\hline Formatív értékelés & $2,40(0,59)$ & $2,37(0,57)$ & 0,99 & 0,32 & 0,66 & 0,51 \\
\hline Kognitív tevékenységek & $2,38(0,43)$ & $2,38(0,51)$ & 1,55 & 0,21 & $-0,20$ & 0,84 \\
\hline Tantárgy klíma & $2,25(0,75)$ & $1,96(0,59)$ & 13,93 & 0,00 & 0,37 & $<0,01$ \\
\hline Tanári támogatás & $2,93(0,56)$ & $3,10(0,46)$ & 5,24 & 0,02 & $-0,31$ & $<0,01$ \\
\hline Tanári osztály-menedzsment & $2,85(0,49)$ & $2,97(0,39)$ & 7,34 & 0,00 & $-0,25$ & 0,01 \\
\hline
\end{tabular}

A tanulók és tanárok földrajztanítással kapcsolatos értékelését összehasonlítva, négy esetben találtunk szignifikáns különbséget. Csak a „kognitív tevékenységeknél” állapítható meg a tanulók javára eltérés $(\mathrm{p}=0,01)$, a többinél, a „direkt instrukciók” $(\mathrm{p}=$ $0,03)$, a „formatív értékelés” $(p=0,04)$, valamint a „tanári támogatás” $(p<0,01)$ esetén pedig a pedagógusok javára figyelhető meg szignifikáns különbség (5. táblázat). Ezek az eredmények azt jelzik, hogy a tanárok önjellemzésük alapján gyakrabban adnak direkt instrukciókat az órán, értékelnek személyre szabottan és támogatják a tanulókat, mint ahogy azt a tanulók látják. A kognitív tevékenységek értelmében viszont a tanulók úgy ítélik meg, hogy a tanárok több gondolkodtató feladatot, illetve kérdést tesznek fel az órán, mint ahogyan azt a tanárok saját véleményük alapján megteszik. 
Kecskeméti Judit - D. Molnár Éva: 8. és 9. évfolyamos tanulók földrajztanulásának sajátosságai

5. táblázat. A tanulók és a tanárok földrajztanitással kapcsolatos tapasztalatai

\begin{tabular}{|l|c|c|c|c|c|c|}
\hline \multirow{2}{*}{ Faktorok } & Tanárok & \multicolumn{2}{c|}{ Tanulók } & \multicolumn{2}{c|}{ Levene } & \multicolumn{2}{c|}{ Kétmintás t/d } \\
\cline { 2 - 7 } & Átlag (szórás) & Átlag (szórás) & $F$ & $p$ & \multicolumn{1}{c|}{$t / d$} & $p$ \\
\hline Tanári segítség & $2,97(0,29)$ & $2,85(0,61)$ & 2,88 & 0,09 & 0,45 & 0,65 \\
\hline Direkt instrukciók & $3,37(0,29)$ & $2,91(0,50)$ & 2,14 & 0,14 & 2,20 & 0,03 \\
\hline Tanulói irányultság & $1,88(0,47)$ & $1,61(0,49)$ & 0,22 & 0,64 & 1,29 & 1,98 \\
\hline Formatív értékelés & $2,88(0,41)$ & $2,38(0,58)$ & 1,16 & 0,28 & 2,05 & 0,04 \\
\hline Kognitív tevékenységek & $1,70(0,60)$ & $2,37(0,47)$ & 0,04 & 0,84 & $-3,45$ & 0,01 \\
\hline Tantárgy klíma & $2,22(0,21)$ & $2,35(0,40)$ & 1,89 & 0,17 & $-0,78$ & 0,44 \\
\hline Tanári támogatás & $3,46(0,43)$ & $2,10(0,69)$ & 2,34 & 0,13 & 4,82 & 0,00 \\
\hline $\begin{array}{l}\text { Tanári osztály- } \\
\text { menedzsment }\end{array}$ & $3,29(0,43)$ & $3,02(0,52)$ & 0,46 & 0,49 & 1,27 & 0,20 \\
\hline
\end{tabular}

\section{A földrajztanulás és -tanítás sajátosságai közötti összefüggések}

A földrajztanulás esetében, akárcsak a többi tantárgy kapcsán az eredményesség mutatója lehet a földrajzjegy, a tanulmányi átlag, valamint a tantárgy (földrajz) iránti pozitív attitüd. Jelen vizsgálatban a három tényező egyikében sem találtunk szignifikáns különbséget a két évfolyam kapcsán. A földrajzjegy és a tanulmányi átlag mindkét évfolyamban a 4-es átlag körüli volt, a földrajz szeretete a 3,10 körüli átlaggal a „közepesen szereti” kategóriába esett.

Lineáris regresszióelemzést végeztünk a földrajzjegyre és a földrajz szeretetére vonatkozóan, és lépésenkénti (stepwise) módszerrel ellenőriztük, hogy a tanulási stratégiák, a tanulási motívumok és a tanítási stratégiák miként magyarázzák ezek alakulását.

A 6. táblázatban függő változóként a földrajzjegy szerepel, független változóként pedig csak azokat a tényezőket vontuk bele, amelyek szignifikáns értékkel bírtak. Első lépésként a háttérváltozók (a földrajz szeretete, nem) magyarázó erejét ellenőriztük, és látható, hogy csupán 26\%-ban magyarázzák a földrajzjegyet. Második lépésben a tanulási motívumokat emeltük be, aminek eredményeként már 38\%-os magyarázóerőt kaptunk, ami azt jelenti, hogy minél magasabb a tanuló intrinzik (belső) motivációja és tanulási önhatékonysága (képességeibe vetett hite), annál jobb lesz a földrajzjegye. A tanulási stratégiák közül nem találtunk szignifikánsan magyarázó tényezőt, és látható, hogy a tanítási stratégiák közül is csak a formatív értékelés kerülhetett be az elemzésbe, ami csupán $1 \%$-kal növelte meg a modell magyarázó erejét $\left(\mathrm{R}^{2}=0,39\right)$. Ezek alapján következtetésként megállapíthatjuk, hogy a földrajzjegy alakulásában közrejátszik a tantárgy szeretete, a tanuló neme (a lányoknak jobb a jegyük), de legmeghatározóbb az, hogy a tanuló mennyire szeretné magát fejleszteni a tantárgyon belül, és mennyire bízik saját képességeiben (hogy meg tudja tanulni a földrajz tananyagot). 


\begin{tabular}{l|l|c|c|c|c|c|c|}
\hline \multicolumn{7}{c}{ 6. táblázat. A földrajzjegy mint függó változó és magyarázó tényezói } \\
\cline { 2 - 8 } \\
\cline { 2 - 8 }
\end{tabular}

De vajon mi határozza meg azt, hogy ki mennyire szereti a földrajz tantárgyat? A kérdés megválaszolására a következő lineáris regressziós modellünkbe a földrajz szeretetét tettük meg függő változónak (7. táblázat). A háttérváltozók (földrajzjegy, nem) 25\%-ban magyarázzák a földrajz szeretetét, ugyanakkor érdemes kiemelni a nemek szerepét, ami ebben az esetben negatív előjellel azt mutatja, hogy a fiúk jobban szeretik a földrajzot, mint a lányok. A modellbe második lépésként beemelt tanulási motívumok (extrinzik motiváció, tanulási önhatékonyság) jelentősen megnövelik a magyarázóerőt (44\%), amit a tanulási stratégiák (idő és környezet szabályozása) és a tanítási stratégiák (tanulói irányultság) csupán néhány százalékkal emelnek tovább. A földrajz szeretetében is (akárcsak a földrajzjegy alakulásában) a tanulási motívumok töltenek be jelentősebb szerepet, de itt, érdekes módon az extrinzik motiváció jelenik meg szignifikáns kapcsolatként, szemben a földrajzjegynél tapasztalt intrinzik motivációval. Ez arra enged következtetni, hogy míg a földrajzjegy azon tanulók esetében magasabb, akiket a belsö ösztönzés, érdeklődés hajt, a földrajz szeretetében meghatározóbb az eredményre, jó jegyre törekvés. A tanítási stratégiák közül azok a tanári instrukciók határozzák meg leginkább a földrajz szeretetét modellünkben $\left(\mathrm{R}^{2}=0,48\right)$, amelyek figyelembe veszik a tanulói igényeket, az egyéni tanulói irányultságokat (személyre szabott oktatási módszernek is nevezhetjük). 
Kecskeméti Judit - D. Molnár Éva: 8. és 9. évfolyamos tanulók földrajztanulásának sajátosságai

7. táblázat. A földrajz szeretete mint függö változó és magyarázó tényezöi

\begin{tabular}{|c|c|c|c|c|c|c|c|}
\hline Modell & Független változók & $B$ & Beta & $t$ & $p$ & $F(p)$ & $R 2$ \\
\hline \multirow{3}{*}{1} & (Konstans) & 1,42 & - & 5,91 & 0,00 & \multirow{3}{*}{$\begin{array}{l}53,49 \\
(0,00)\end{array}$} & \multirow{3}{*}{0,25} \\
\hline & Neme & $-0,21$ & $-0,10$ & $-2,13$ & 0,03 & & \\
\hline & Jegy & 0,55 & 0,50 & 10,32 & 0,00 & & \\
\hline \multirow{5}{*}{2} & (Konstans) & 0,61 & - & 2,68 & 0,01 & \multirow{5}{*}{$\begin{array}{l}63,02 \\
(0,00)\end{array}$} & \multirow{5}{*}{0,44} \\
\hline & Neme & $-0,11$ & $-0,05$ & $-1,25$ & 0,21 & & \\
\hline & Jegy & 0,23 & 0,21 & 4,09 & 0,00 & & \\
\hline & Extrinzik motiváció & 0,09 & 0,13 & 2,54 & 0,01 & & \\
\hline & $\begin{array}{l}\text { Tanulási } \\
\text { önhatékonyság }\end{array}$ & 0,33 & 0,44 & 7,40 & 0,00 & & \\
\hline \multirow{6}{*}{3} & (Konstans) & 0,12 & - & 0,39 & 0,70 & \multirow{6}{*}{$\begin{array}{l}52,50 \\
(0,00)\end{array}$} & \multirow{6}{*}{0,45} \\
\hline & Neme & $-0,11$ & $-0,05$ & $-1,24$ & 0,22 & & \\
\hline & Jegy & 0,23 & 0,21 & 4,01 & 0,00 & & \\
\hline & Extrinzik motiváció & 0,08 & 0,11 & 2,06 & 0,04 & & \\
\hline & $\begin{array}{l}\text { Tanulási } \\
\text { önhatékonyság }\end{array}$ & 0,31 & 0,42 & 6,96 & 0,00 & & \\
\hline & Az idő és a környezet & 0,16 & 0,11 & 2,51 & 0,01 & & \\
\hline \multirow{7}{*}{4} & (Konstans) & $-0,49$ & - & $-1,50$ & 0,13 & \multirow{7}{*}{$\begin{array}{l}48,67 \\
(0,00)\end{array}$} & \multirow{7}{*}{0,48} \\
\hline & Neme & $-0,09$ & $-0,04$ & $-1,00$ & 0,32 & & \\
\hline & Jegy & 0,25 & 0,23 & 4,51 & 0,00 & & \\
\hline & Extrinzik motiváció & 0,09 & 0,12 & 2,36 & 0,02 & & \\
\hline & $\begin{array}{l}\text { Tanulási } \\
\text { önhatékonyság }\end{array}$ & 0,29 & 0,39 & 6,69 & 0,00 & & \\
\hline & Az idő és a környezet & 0,15 & 0,11 & 2,41 & 0,02 & & \\
\hline & Tanulói irányultság & 0,35 & 0,17 & 4,09 & 0,00 & & \\
\hline
\end{tabular}

\section{Összegzés}

Empirikus kutatásunkkal arra kerestük a választ, hogy a földrajz tantárgy tanulásával és tanításával kapcsolatos tapasztalatok mennyiben igazolják vagy cáfolják a tanulásról szerzett eddigi ismereteinket. Ha az eddigi kutatási eredményekkel összehasonlítjuk a jelen vizsgálat végeredményeit, akkor megállapíthatjuk, hogy az ismétlés még mindig magas arányban van jelen a tanulóknál, függetlenül az iskolafokozat jellegétől, ugyanakkor a fejlettebb stratégiahasználatra utaló megszervezés vagy metakognitív stratégiák használata is megjelenik a földrajztanulásban (vö. Csullog és mtsai, 2014). Megfigyelhető volt ugyanakkor az is, hogy mindkét évfolyamon a legkevesebb hangsúly a kritikai gondolkodásra tevődött, melynek fejlesztése még európai viszonylatban is ,gyerekcipőben" jár (vö. Jucu, 2012), de az iránta való érdeklődés már hangsúlyosabb, mint hazai körökben.

Kiderült ugyanakkor az is, hogy a diákok többsége inkább önállóan, mint csoportban készül fel a tanórákra, vagyis a kooperatív tanulási stratégiák használata meglehetösen alacsony szinten funkcionál. Hasonló eredmény született az általános tanulási stratégiák használata kapcsán is (D. Molnár, 2013), ami vélhetően nehezítheti a későbbi, munkaerö-piaci elvárásoknak való megfelelést (hatékony együttmüködés, csoportban való dolgozás). 
A tanulók motiváltságát illetően jelen vizsgálat során is kiemelkedett az extrinzik motívumok szerepe, ami a jó jegy elérésében nyilvánul meg, de a tanulási önhatékonyság és a tanulási meggyőződés szabályozása is közel azonos értékeket mutatott. Kiderült továbbá, hogy a földrajzjegy és a földrajz szeretetének alakulásában döntően meghatározó a tanulási motiváció, azon belül is a tanulási önhatékonyság bír a legerősebb szignifikáns kapcsolattal. Tehát az a tanuló, aki bízik saját képességeiben, bízik abban, hogy meg tudja

A tanulók motiváltságát illetốen jelen vizsgálat során is kiemelkedett az extrinzik motínumok szerepe, ami a jó jegy elérésében nyilvánul meg, de a tanulási önhatékonyság és a tanulási meggyózódés szabályozása is közel azonos értékeket mutatott. Kiderült továbbá, hogy a földrajzjegy és a földrajz szeretetének alakulásában döntốen meghatározó a tanulási motiváció, azon belül is a tanulási önhatékonyság bir a legerốsebb szignifikáns kapcsolattal. tanulni a földrajz tananyagot, magasabb eredményekkel rendelkezik, és jobban is szereti a földrajz tantárgyat (vö. Csullog és mtsai, 2014). Ezek alapján kézenfekvőnek látszik az a felvetés, hogy a továbbiakban érdemes lenne nagyobb hangsúlyt fektetni ezen motívum tudatosabb fejlesztésére.

Megfigyelhető, hogy bár a fiatalabb (szerkezetváltás elött álló) korosztály számos stratégia és motívum használatát tekintve alulmarad az idősebb korosztálytól, a nyolcadikosok mégis jelentősebbnek tartják a földrajz tanulásának a fontosságát, mint a kilencedikesek, ami valamiképp igazolja az általános iskola szerepét a természettudományos érdeklődés kialakításában és megtartásában (Nagy, 2010). Ezzel együtt az is megállapítható, hogy a szerkezetváltást követően a diákok már a földrajztanulással kapcsolatos viselkedésük és erőkifejtésükre helyezik inkább a hangsúlyt, ami leginkább az intézmény szerepkörének elvárásaihoz köthetö, vagyis már nem azon van a legnagyobb hangsúly, hogy mit, hanem azon, hogy miként sajátítják el az adott tananyagot (Nagy, 2010).

A földrajzórákkal, földrajz tanításával kapcsolatos tanulói tapasztalatok többsége negatívabb, mint az ezzel összehasonlításban lévő tanári tapasztalatok. A tanárok önjellemzése és a tanulók véleménye közötti eltérés összefüggésbe hozható az elözetes tudás felmérésének elhanyagolásával is (Korom és Csapó, 1997). A tanárok úgy érzik, gyakran adnak direkt instrukciókat a diákok számára, a tanulók viszont úgy gondolják, hogy a tanárok több gondolkodtató kérdést tesznek fel, ami jelen esetben nem biztos, hogy pozitívnak tekinthetö, mivel a bizonytalan alapokra való építkezés miatt ítélhetik a kérdéseket nagyobb gondolkodást igénylőnek (vö. Makádi és Horváth, 2011).

Összességében elmondható, hogy a jelen kutatás jól illeszkedik a tanulás folyamatáról való eddigi gondolkodásunkhoz, és további adatokkal járul hozzá az egyes tantárgyi területeken végzett vizsgálatokhoz (vö. Csíkos, 2012). Eredményeink egyrészt irányadóak a természettudományos tantárgyakon belüli tanulási motívumokat és stratégiahasználatot tekintve, másrészt tájékoztató jellegủ információkat is tartalmaznak a tanulók és tanáraik földrajztantárgyról (és a szaktanárról) alkotott nézeteiről.

A második szerző a tanulmány megírása alatt Bolyai János Kutatási Ösztöndíjban részesült. 


\section{Irodalomjegyzék}

Bekéné Zelencz Katalin (2012): A tanulási motiváció kialakulását segítő pedagógus attitüdök. Új Pedagógiai Szemle, 62. 9-10. sz. 141-144.

B. Németh Mária, Habók Anita (2006): A 13 és a 17 éves tanulók viszonya a tanuláshoz. Magyar Pedagógia, 106. 2. sz. 83-105.

Chandler, Simon (2011): Gondolkodtató földrajz 2. Módszertani útmutató a földrajz tanításához. Müszaki Kiadó, Budapest

Csapó Benő (2000): A tantárgyakkal kapcsolatos attitüdök összefüggései. Magyar Pedagógia, 100. 3. sz. 346-366.

Csíkos Csaba (2012): Melyik a kedvenc tantárgyad? Iskolakultúra, 22. 13. sz. 3-16.

Csullog Krisztina, D. Molnár Éva és Lannert Judit (2014): A tanulók matematikai teljesítményét befolyásoló motívumok és stratégiák vizsgálta a 2003-as és a 2012-es PISA-mérésekben. In: Hatások és különbségek. Másodelemzések a hazai és nemzetközi tanulói képességmérések eredményei alapján, Oktatási Hivatal, Budapest. 167-215.

D. Molnár Éva (2013): Tudatos fejlödés. Az önszabályozott tanulás elmélete és gyakorlata. Akadémiai Kiadó, Budapest.

Farsang Andrea (2011): Földrajztanitás korszerüen. GeoLitera SZTE TTIK Földrajzi és Földtani Tanszékcsoport, Szeged

Fejes József Balázs (2014): A kontextus szerepe a tanulási motiváció kutatásában - az elmélet és a gyakorlat távolságának egy megközelítése. Magyar Pedagógia, 114. 2. sz. 115-129.

Hidi, S. (2001): Interest, Reading and Learning: Theoretical and Practical Considerations. Education Psychology Rev., 13. 3. sz. 191-210.

Horváth H. Attila (2009): A pedagógus-kulcskompetenciák szerepe a tanulók versenyképességében, OFI, Vitafórum [ http://ofi.hu/tudastar/vitaforumok/pedagogus - Letöltés: 2016. július 15.]

Elizabeth R. Hinde (2015) Geography matters: Teacher beliefs about geography in today's school. The Journal of Social Studies Research, 39. 55-62. DOI: 10.1016/j.jssr.2014.07.003

Józsa Krisztián és Fazekasné Fenyvesi Margit (2007): A tanulásban akadályozott gyerekek tanulási motivációja. Iskolakultúra Online, 1. 76-92.

Józsa Krisztián (2007): Az elsajátitási motiváció. Müszaki Kiadó, Budapest

Józsa Krisztián, Fejes József Balázs (2012): A tanulás affektív tényezői. In: Csapó Benő (szerk.): Mérlegen a magyar iskola. Nemzeti Tankönykiadó, Budapest. $367-406$.
Ioan Sebastian Jucu (2012): Rethinking geography in Romanian Schools: curricular changes in geography learning in post-socialist Romania. Social and Behavioral Sciences, 46. 5440-5448. DOI: 10.1016/j. sbspro.2012.06.454

Kádár Anett és Farsang Andrea (2012): Általános és középiskolás tanulók földrajz tantárgyhoz köthetö tévképzetei. In: Nyári Diána (szerk.): Kockázat-Konfliktus-Kihívás, VI. Magyar Földrajzi Konferencia, SZTE TTK, Természetföldrajzi és Geoinformatikai Tanszék, Szeged. 339-353.

Kálmán Orsolya (2009): A hallgatók tanulási sajátosságai és ezek változása. Phd-értekezés, Eötvös Loránd Tudományegyetem Pedagógiai és Pszichológiai Kar, Neveléstudományi Doktori Iskola, Budapest [http://www.kalmanorsolya.hu/sites/default/files/Kalman Orsolya A hallgatok tanulasi disszertacio.pdf Letöltés: 2015. fēbruár 10.]

Kormány Gyula (2014): Öntevékenységre nevelés a földrajzoktatás folyamatában. A földrajz tanitása. 1. $37-41$

Korom Erzsébet és Csapó Benő (1997): A természettudományos fogalmak megértésének problémái. Iskolakultúra, 7. 2. sz. 12-20.

Lappints Árpád (2002): Tanuláspedagógia. A tanulás tanitásának alapjai. Comenius Bt., Pécs

Makádi Mariann, Farkas Bertalan Péter és Horváth Gergely (2013): Tanulási-tanitási technikák a földrajztanitásban. Eötvös Loránd Tudományegyetem, Budapest

Makádi Mariann és Horváth Gergely (2011): A földrajz és a természettudományok. In: Földrajzi Közlemények, 135. 2. 179-184.

Makádi Mariann (2011): A földrajztanárok módszertani kultúrája. Földrajzi Közlemények, 135. 2. sz. $125-133$.

Mansfield, C. és Volet, S. (2010): Developing beliefs about classroom motivational: Journeys preservice teacher. Teaching and teacher Education, 26. 14011415. DOI: $10.1016 /$ j.tate.2010.04.005

Dr. Nagy Béla (2010): A természettudományos oktatás fejlesztése a Varga Katalin Gimnáziumban. Szegedi Tudományegyetem Közoktatási Vezetőképző Intézet, Szeged

Nahalka István (2013): A természettudományos nevelés helyzete Magyarországon a kerettantervek írása idején. Tani-tani Online [Utolsó letöltés: http://www. tani-tani.info/a termeszettudomanyos - 2016. március 7.$]$

NAT (2012): Nemzeti alaptanterv. - Nyilvános vitaanyag, Oktatási Minisztérium [https://www.ofi.hu/ sites/default/files/attachments/mk nat 20121.pdf Letöltés: 2015. június 9.] 
Ollé János (2010): Tanitási-tanulási stratégiák az oktatási folyamatban. Doktori értekezés Eötvös Loránd Tudományegyetem Pedagógiai és Pszichológiai Kar, Neveléstudományi Doktori Iskola, Budapest, [http://issuu.com/ollejanos/docs/tanitasitanulasistrategiakazoktatasifolyamatban Utolsó letöltés: 2015. április 20.]

Pintrich, P. R. (1989): The dynamic interplay of student motivation and cognition in the college classroom. In: Ames, C. és Maehr, M. (szerk.): Advances in motivation and achievement: Vol. 6. Motivation enhancing environments. JAI Press, Greenwich. $117-160$.

Pintrich, P. R., Smith, D. A. F., Garcia, T. és McKeachie, W. J. (1991): A manual for the use of the Motivated Strategies for Learning Questionnaire (MSLQ). Suite 2400 School of Education Building, Ann Arbor, Michigan

OECD (2012): OECD Programme for International Student Assessment 2012 - Tanulói kérdőív B. DOI: 10.1787/9789264167872-2-en

Takács Viola (2001): Tantárgyi attitüdök struktúrája. Magyar Pedagógia, 101. 3. sz. 301-318.

Tóthné Kosztin Beáta (2011): Egy kisérleti oktatási módszer hatásai a természettudományos fogalmi fej- lödésre, problémamegoldásra és más pszichológiai tényezökre. Phd-értekezés, Debreceni Egyetem [https://dea.lib.unideb.hu/dea/bitstream/handle/2437$/ 118268 / \mathrm{T} \% \mathrm{C} 3 \% \mathrm{~B} 3$ thn $\%$ C3\%A 9\%20Kosztin Be $\%$ C3\%A1ta \%C3\%A9rtekez $\%$ C3\%A9s-t.pdf?sequence $=5 \&$ isAillowed $=y$ Letöltés: 2015 . július 9.]

Ütőné Visi Judit (2002): A földrajz tantárgy helyzete és fejlesztési feladatai. Pedagógiai Szemle. [http:/ folyoiratok.ofi.hu/uj-pedagogiai-szemle/a-foldrajztantargy-helyzete-es-fejlesztesi-feladatai - Letöltés: 2016. július 10.]

Ütőné Visi Judit (2009): A földrajz tantárgy helyzetét és fejlesztési feladatait feltáró tanulmány. Kérdőíves elemzése felmérés alapján [http://ofi.hu/foldrajz-tantargy-helyzetet-es-fejlesztesi-feladatait-feltaro-tanulmany-kerdoives-elemzese-felmeres - Letöltés: 2016. július 10.]

Ütőné Visi Judit (2011): Helyzetkép és lehetőség A földrajzoktatásról egy felmérés tükrében. Földrajzi Közlemények, 135. 2. sz. 115-123.

Vermut, J. és Verloop, N. (1999): Congruence and friction between learning and teaching, Learning and instruction, 9. 257-280. DOI: 10.1016/s09594752(98)00028-0 